\title{
APPLICATION OF EXPOSED CONCRETE AT ERECTION OF MONOLITHIC BUILDINGS
}

\author{
Antonina Yudina1, Mikhail Ponomarev² \\ 1,2 Saint Petersburg State University of Architecture and Civil Engineering, \\ Vtoraja Krasnoarmejskaja ul. 4, St. Petersburg, 190005, Russia. \\ ${ }^{1}$ yudinaantonina2017@mail.ru, ${ }^{2}$ ponomarevmih@mail.ru
}

\begin{abstract}
In the present paper, we consider improvement of the cast-in-place construction technology with the application of exposed (architectural) concrete, which allows implementing the boldest ideas of architects directly on a construction site, transforming cast reinforced concrete into the category of architectural front surface. We also consider the perspectives of the technology development in Russia and abroad. We show the examples of the exposed concrete designs implemented in the European countries. We give a description to the technology of exposed concrete; define the concepts of "exposed" and "self-cleaning" concrete. In addition, we consider the advantages of exposed concrete, the content, kinds, purpose and technical characteristics of architectural and self-cleaning concrete, as well as the factors influencing the result of concreting when using this technology.
\end{abstract}

Key words: technology of exposed concrete, architectural concrete, self-cleaning concrete

\section{Introduction}

In the modern society, there is a growing demand for erection of really unique and original buildings and structures. In fact, there are few brand new construction technologies in Russia. One of the reasons for such a small number of technologies is the lack of well-trained skilled specialists. Especially acute is the problem of the lack of bold solutions of architects, precise dimensioning calculation of designers and line construction management personnel, who implement the ideas created by the architects on paper.

The construction branch is currently developing in Russia at a fast rate. Special attention is paid to the erection of unique buildings. It is primarily caused by the entrance of Russia to the international level: the Olympics-2014, FIFA World Cup-2018 as well as running various international competitions. There is a need in developing original designs and new advanced technologies of work performance for their implementation.
Generally, innovative technologies come to Russia from abroad, and the erection of cast-in-place buildings made from exposed concrete may be considered as an example of such a technology. The aim of this technology is the construction of not only individual buildings and structures, but also creation of a new architectural landmark of an entire city, underlining its exclusive architectural expression.

Studying the foreign experience in the sphere of castin-place construction, it may be concluded that the technology of exposed concrete buildings and structure erection is increasingly applicable.

This technology makes it possible to erect buildings and constructions of various categories from residential houses to unique structures of a special purpose. The examples of their implementation are shown in the end of the paper.

Description of exposed concrete is not always categorical and there are various definitions in the existing regulations. Basically, exposed concrete is usually the el- 
ements of a construction, which remain visible after final completion.

Exposed concrete structures are modern constructions, built according to unique designs with the opportunity of free choice of an architectural form and methods of front surface finishing. Preparation and implementation of the designs with the use of exposed concrete requires special skills on the issues of calculation and designing as well as erection of these structures.

Exposed concrete is often defined as visible concrete, which provides many opportunities for various interpretations. As there are currently no regulations on the execution of architectural concrete finishing in Russia, all the details of the process should be included into the technical documentation of a contract. (Shilstone, 1985)

In Russia, study and application of the exposed concrete technology is of small account. Nevertheless, it is currently being introduced thanks to a design of the Foster + Partners architectural bureau, which is notable for its bold architectural solutions. Contrary to the ordinary reasoning of Russian builders, Norman Foster has suggested transferring cast-in-place reinforced concrete to the category of architectural front surface. The design has been developed at the commission of the Russian Copper Company (RMK) in Yekaterinburg. It is no wonder that the basis for development of the architecture of the building has become the structure of copper pattern. Also, in the design of the building it was suggested using the copper color. According to the Director of Communications and Social Policy of the RMK Evgeniy Chaplygin, the future head office of the RMK will attract attention and bring a special charm to the city environment of Yekaterinburg, as it is now in other major cities of the world (Gusev, 2014).

From the structural point of view, the building is a framed monolithic system, with supporting columns from 5 to $11 \mathrm{~m}$ in height and intermediate concrete slabs as the core elements. The material for the structural elements of the building is "white" (exposed) concrete.

Practical implementation of this really unique design, study and testing of the innovative technology of exposed concrete is implemented by the "ATOMSTROYKOMPLEKS" Construction Management", Nonprofit Partnership of "EGS-Garant" LLC. There are many issues arising in the process of construction of the specified design, and up to now, the final decision on the implementation of this technology has not been made.

The basic requirements to the exposed concrete designs:

- underlining the uniqueness and singularity of the structure;

- ensuring purposefulness and usefulness of the structure;

- free choice of finishing the front surfaces (step of the modular grid, joints and texture);

- support of the designs' development when erecting unique buildings and structures, free choice of expressive elements and their decoration. In this particular sense, monolithic concrete provides a certain freedom of choice for architectural forms and implementation of these requirements.

\section{Materials and methods}

'Exposed' (architectural) concrete (Latin Architectura, from Ancient Greek $\alpha \rho X I$ - senior, chief and

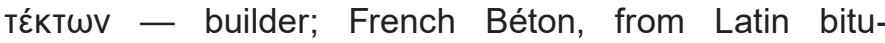
men - earth pitch, asphalt) is a construction mix based on concrete and sand composition with various mineral and nonorganic additives. Architectural concrete bears both supporting and structural load, and carries out a decorative and applied task having a high artistic and aesthetic value (see http://esthetiks.ru).

Word combinations: "exposed concrete", "white concrete", "polymer concrete", "acryl concrete", "artistic concrete", "decorative concrete" are the synonyms of architectural concrete. The term "architectural concrete" has been formed in the professional environment of architects for determination of a construction material suitable for creation of finished architectural designs (Nekrasova, Nekrasov, Sadikova, 2008).

\section{Kinds and purpose of architectural concrete}

Architectural concrete is a hi-tech construction material, providing a wide range of opportunities. There are three main directions of concrete application: creation of structures, designs, and foundations (monolithic, reinforced concrete etc.); application of concrete with the decorative purpose as a material for finishing ready surfaces; creation of volumetric artistic designs - the third direction unites structural and decorative properties of architectural concrete: basically, the form is united with the texture and facture (Rossiiskaya Federatsiya, 1995).

Depending on the final purpose, it is possible to change the mix composition in order to obtain concrete with structural and decorative properties:

1. Geometric concrete is concrete where structural properties prevail, used for creation of monolithic structures of various forms with application of different formwork types;

2. Decorative concrete is concrete where decorative properties prevail in the mix, used for finishing and decorating of ready surfaces;

Concrete with prevailing geometrical properties, as it has been already considered above, has been widely used in Germany as a material solving many tasks of structural physics (see http://www.beton.org/). It is applied in construction of modern buildings, facing, creation of new facades, interior finishing, and modification of room shapes (Schild, 1982). Due to durability of concrete structures, high endurance structural characteristics, and variety of forms, architectural concrete has become the most popular material for erection of large structural designs of various geometries, being casted by means of formwork (Korchagina, 2004).

Decorative (architectural) concrete has been known together with concrete for over 100 years and successfully replaces natural stone, gypsum and grog refractory. Architectural concrete is currently used for production of any kinds of items, such as walkway slabs and large mon- 
umental sculptures, which may be made almost in any color.

\section{Composition of architectural concrete}

Depending on the set tasks, the composition of a concrete mix may be changed thanks to application of various additives, which either enlarge structural properties (stableness, durability, water repellency etc.) or improve the decorative peculiarities (facture, texture).

To modify the facture and texture of architectural concrete, the composition may include such compounds as granite, marble, basalt, quartzite, mica and particles of rock formations.

In order to obtain colorful concrete, white and color pigments are applied. The most commonly used are mineral pigments, which are generally oxides or salts of various metals. There are different organic pigments and coloring agents, which ensure intensive coloring of concrete by a small amount of inclusion. In order to obtain homogenous coloring of concrete, special smoothing additives are used.

Technical characteristics of architectural concrete

Besides its uniqueness, there are also the other positive peculiarities:

1. technical characteristics of exposed concrete excel the peculiarities of traditional concrete by several times, which is achieved by a special method of pouring the binder solution and application of special additives (modifiers and plasticizers)

2. resistance to corrosion environments (atmospheric precipitations, differential temperature - from $-50{ }^{\circ} \mathrm{C}$ to $+50{ }^{\circ} \mathrm{C}$ etc.)

3. the surface does not require subsequent finishing, which in its turn is economically viable

4. it has its own facture, which is widely used by hitech architects and designers in implementation of their ideas

5. it is easily washable

6. it does not bleach

7. highly resistant to ultraviolet rays

8. highly resistant to pressure and wearing-off

9. highly shock-proof

10. highly resistant to penetration of chlorides
11. high gas impermeability

12. adjustable indexes of deformability, including compensation of architectural concrete shrinkage at the age of 14-28 days of natural maturing

13. comparatively low specific gravity (does not constitute a heavy load on foundations)

14. good acoustic absorption coefficient

15. fireproof material

16. environmentally sound material

Combining the properties of geometric and decorative concrete, it is possible to vary configuration and decoration of the building. Nevertheless, in the European countries the study of other opportunities of cast-in-place construction is still in progress; it is being conducted by modifying the composition of concrete and improving the technology of concreting.

In Germany, significant efforts are currently applied to develop self-cleaning monolithic surfaces or the surfaces which will be easy to clean. Notably, there are early developments in this direction for certain facades. These surfaces got the name of self-cleaning concrete (Cassar, 2004).

There are generally two approaches in order to obtain a self-cleaning surface:

1. The surface should be highly water-repellent (a super-hydrophobic surface);

2. The surface should be highly hydroscopic, i.e. it should collect water (a super-hydrophilic surface). As building facades of this kind have a thickening, resembling a leaf surface by its geometry, which makes dirt remove from the facade and easily flow down with rain drops; in this regard, such a form is called "lotus effect".

\section{Super-hydrophobic surfaces}

To achieve a high hydrophobic effect, the material is modified or coated with silicon resin or tetrafluoroethylene - thus, water drops can easily slide down from the surface. Although, the problem arises in connection with the fact that too small drops cannot entirely slide down and remain with the particles of dirt (dust), dry and form dark fragments on the surface.

Table 1. Technical Characteristics of Architectural Concrete Structures

\begin{tabular}{|c|c|c|c|c|}
\hline No. & Product parameters & Unit & $\begin{array}{c}\text { According to the require- } \\
\text { ments of GOST 1760891 }\end{array}$ & De facto \\
\hline 1 & Quality class: by compression capacity & $\mathrm{kg} / \mathrm{cm}^{2}$ & $\begin{array}{c}\text { B22.5-B30 } \\
(300-450)\end{array}$ & B30 min 450 \\
\hline 2 & Freeze-thaw resistance class (in salts) & - & $\mathrm{F} \mathrm{200}$ & $\mathrm{F} 350$ \\
\hline 3 & Absorption of water & $\%$ & 5 & 4.4 \\
\hline 4 & Wearing capacity (GOST 13015.0) & $\mathrm{g} / \mathrm{cm}^{3}$ & $0.9-0.7$ & $0.2-0.3$ \\
\hline 5 & $\begin{array}{c}\text { Deviation of geometrical param- } \\
\text { eters: length, width, thickness }\end{array}$ & $\mathrm{mm}$ & $+5+5$ & $+1+1$ \\
\hline 6 & Cement-water ratio (c/w) & $\%$ & 45 & 17 \\
\hline 7 & Category of front surface & - & $\mathrm{KPE}-\mathrm{KPZ}$ & $\mathrm{KP} 1$ \\
\hline 8 & $\begin{array}{c}\text { Resistibility in 24 hours in the } \\
\text { process of natural maturing }\end{array}$ & $\mathrm{MPa}$ & & $25-30$ \\
\hline
\end{tabular}




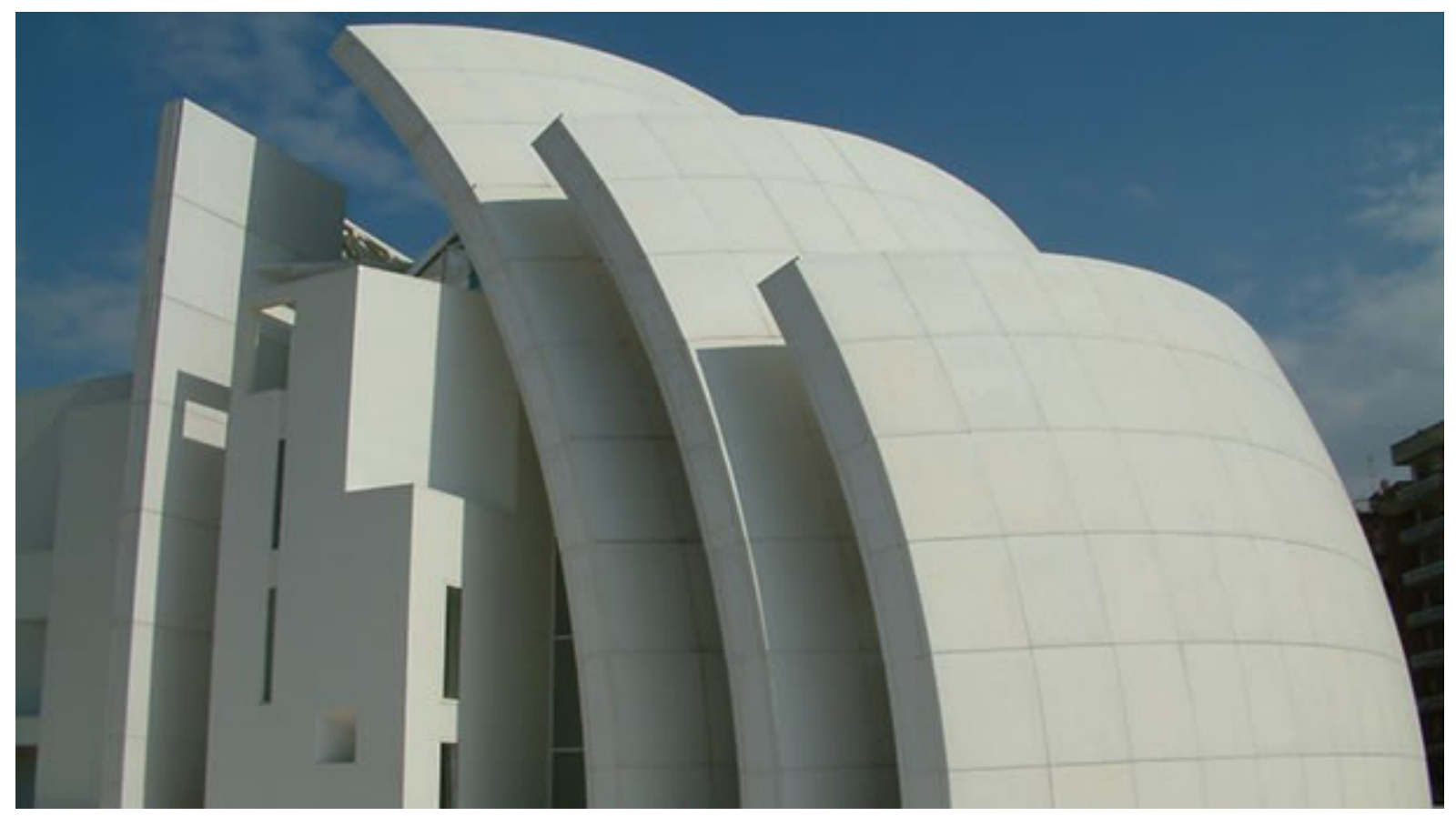

Photo 1. The church made from self-cleaning concrete always keeping its whiteness, "Rich in Mercy", Dives in Misericordia, Rome.

\section{Super-hydrophilic surfaces}

Thus, super-hydrophilic surfaces are a more promising alternative. They have a thin microindented structure; dirt particles are bigger than microscopic particles on the surface of the material, that is why all the little dirt particles gravitate to the "tips" of the particles. Thus, dirt particles have very low adhesion and easily flow down with water drops.

The surface is modified through using photocatalysts. These chemical substances are activated by light (ultraviolet rays) and destroy dirt, thus cleaning the surface.

Titanium dioxide plays the role of catalyst, which being exposed to ultraviolet (sun rays) decomposes many harmful substances (e. g. nitrogen oxides) and also kills bacteria (Cassar, 2008).

Besides, $\mathrm{TiO}_{2}$ is used in concrete structures because this chemical element weakly interacts in the alkaline environment of concrete and is not visible on its surface.

The following methods are used to spread the agent on a concrete surface:

1. Spraying the $\mathrm{TiO} 2$ solution to a surface;

2. Submergence of a reinforced concrete element into a special pool with the $\mathrm{TiO} 2$ solution;

3. Creation of a layer by means of jelly applied directly to a surface.

The methods specified above have the only disadvantage - low resistance to mechanical effects. In this regard, some attempts are being undertaken to include photocatalysts into the concrete mix composition. In this case, the inner layer also contains $\mathrm{TiO}_{2}$ at damaging or wearing off of the upper layer and the basic material, thus keeping the function of self-cleaning.

The related research turned out to be possible due to the development of nanotechnologies, because the catalyst properties of titanium dioxide manifest themselves most actively only when it is applied in a very thin layer or in the form of microscopic particles.

Swedish engineers suggest that it is high time to actively introduce this photocatalyst into the urban development and are intended to promote the related research, and, moreover, to produce such construction materials and, particularly, concrete mixes in lots.

Despite its higher price as well as unfavorable correlation between large air masses and comparatively small areas covered by the catalyst, the first testing has shown it to be effective.

A concrete structure created with the purpose of purifying the air in road tunnels seems especially attractive.

The first operational experience of construction with the application of photocatalysts took place in the USA and Japan, though mainly for ceramic construction materials such as tile. In Italy, self-cleaning concrete was propelled to a higher level: in 2003, the church Dives in Misericordia ("Rich in Mercy") was built in Rome (Photo 1). It was designed by the American architect Richard Meier.

Notably, construction from any kind of innovative material cannot be imagined without improving the technology of construction operations. Any improvement of physical and chemical properties of a concrete mix causes change of concreting methods. 


\section{Methods and manufacturing technology of ex- posed concrete structures}

The entire process of work with architectural concrete has been thus far generally performed in plant conditions with a certain limited number of related equipment. Manufacturing of reinforced concrete monolithic structures with application of such concrete has scarcely been conducted in situ. This fact generally relates to so-called decorative concrete.

In our research, we suggest paying more attention to geometric concrete and some erection projects of the framed and monolithic buildings, with their bearing structures made from exposed concrete.

It must be noted that except for the reliability and performance together with space arrangement in the context of implementing a design with the application of exposed concrete, the crucial part is primarily played by front surfaces and their appearances. They fulfill the function of architectural decoration and that is why such front surfaces are also called "concrete surfaces with strict requirements to appearance". In August 2004, 'Deutsche Beton- und Bautechnik-Verein E.V.' (DBV) together with 'Bundesverband der Deutschen Zementindustrie e. V.' (BDZ) published the third (after 1977 and 1997) edition of the Standards on the Use of Architectural Concrete. For the first time, the document contains four classes from SB 1 to SB 4, which differ by the requirements to texture, voids rating, color consistence, smoothness and the quality of the joints between the structural elements and the formwork joints (Deutscher Beton- und Bautechnik-Verein e.V. (DBV) Bundesverband der Deutschen Zementindustrie (BDZ),2015). Other requirements are connected with surface examination. The main part contains comments on the designing procedure and the invitation of bids, as well as on their implementation. It is based on the construction experience of significant structures made from architectural concrete over the last years. The last part comprises the discussion of the architectural concrete surface examination. The main principle consists in the fact that the first and the defining criterion is a general impression. (Litzner, Goldammer, 2005).

This Code of Regulations and Standards does not only set the corresponding categories according to advanced demands, but also defines the measures which are necessary to be applied at the stage of the work performance. It also provides a review of design methods and works to be performed. A particular focus is set on improvement of the results, which can be achieved with the use of white cement. (Heess, 2009).

Special requirements for the quality are imposed to the formwork of exposed concrete, and it is necessary to keep in mind specific price factors for it. For front surfaces to correspond to the expectations of an architect and customer, it is necessary, in our opinion, to elaborate all the working operations beforehand, their order and terms from the perspective of all the participants of the project, responsible for the quality of the concrete. There is a special regulatory system, which allows considering all the factors influencing the result.
1. Availability of agreed or, correspondingly, approved design documentation, preferably on electronic media;

2. If possible, availability of initial drawings of the building before the start of finishing works (depicting only bearing walls and floor structures);

3. Specific guidelines on which surfaces should be exactly finished with exposed concrete;

4. Definition of a layout of the formwork arrangement;

5. Agreement of marking drawings (with plans and sections) for complicated fragments of front surfaces (in the areas of joints between the walls and floor structures);

6. Accounting of concrete inserts, which may influence the appearance of the front surfaces (lighting, pipes etc.);

7. Definition of construction joints arrangement by agreement with a strength design specialist;

8. Discussing the issues with everybody who works on the construction and finishing of the front surfaces on the site;

9. Clarifying which requirements to a surface are connected with low and high labor contribution;

10. Taking measures to protect exposed concrete fabricated parts in the process of further construction works;

11. The necessity to create precise geometry of the formwork;

12. The smooth surface of the front part of the formwork contacting with concrete should not have any minimal scratches, splits, and cracks.

A number of specialists and construction workers take part in the process of finished product creation, in particular: architects, designers, concrete factories, formwork system specialists, and line technical engineering personnel.

Precise distribution of responsibility areas in the process of work with the exposed concrete at erection of framed monolithic buildings is an important part of success. Exposed concrete is the result of the team work.

The peculiarities of front surface formation and the methods of concrete mix casting should be considered in a separate paper.

\section{The Exposed Concrete Designs Brought to Life}

\section{Residential House in Petrisberg}

In collaboration with the customer, architectural bureau Denzer \& Poensgen, Cologne has developed an unusual concept of a living space arrangement: a building with residential area of about $470 \mathrm{~m}^{2}$ at 3 levels, finished with the maximum application of exposed concrete and built upon historical traditions of the Roman architecture, which are prevalent in Trier. Well-defined structure of space with paths, free areas, passages, internal and external rooms creates a great impression. It is like a small town: though being externally humble enough it amazes its habitants and guests by its internal architecture - there is even an atrium in the form of oasis with a pond and a garden. 


\section{Architecture and Engineering Volume 1 Issue 2}

Location:

Trier, Germany

Installation and Construction Work: Josef Schmitz GmbH, Grosslittgen Architect:

Denzer \& Poensgen, Cologne
Formwork:

Beam formwork Top 50

Bottom:

Sandwich slab with film coating

Peculiarity:

Grid of joints and anchor clampings with a calculated step
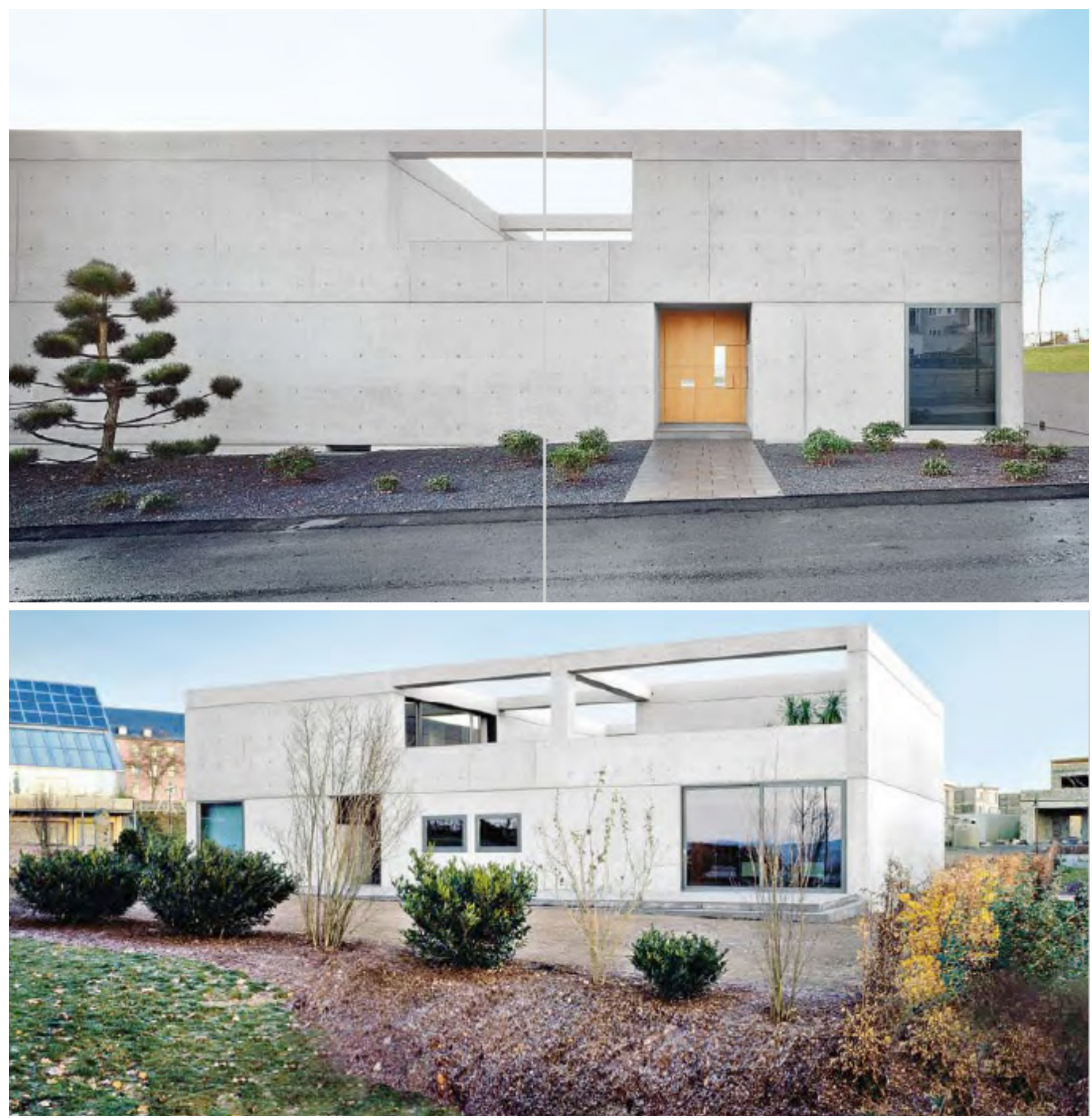
Pilot Residential Estate in Heidersdorf, building 6 Location:

Vienna, Austria

Installation and Construction Work:

Strabag, Vienna

Architect:

Roger Diener, Basel

Formwork:

Beam formwork FF20

Bottom:

Structural slab 3-SO
The structural slab is attached to the FF20 beam formwork from the side, not contacting with concrete, anchor clampings and suspension points for decking are located with a calculated step.

Architectural bureau Krischanitz has built a pilot residential estate at a parcel of $8,000 \mathrm{~m}^{2}$ on the outskirts of Vienna. It consists of 10 residential houses. Nine famous architects from Austria, Germany and Switzerland were involved in development of the design. According to the project terms, the building should have been made entirely from concrete in order to show the diversity of its forms.

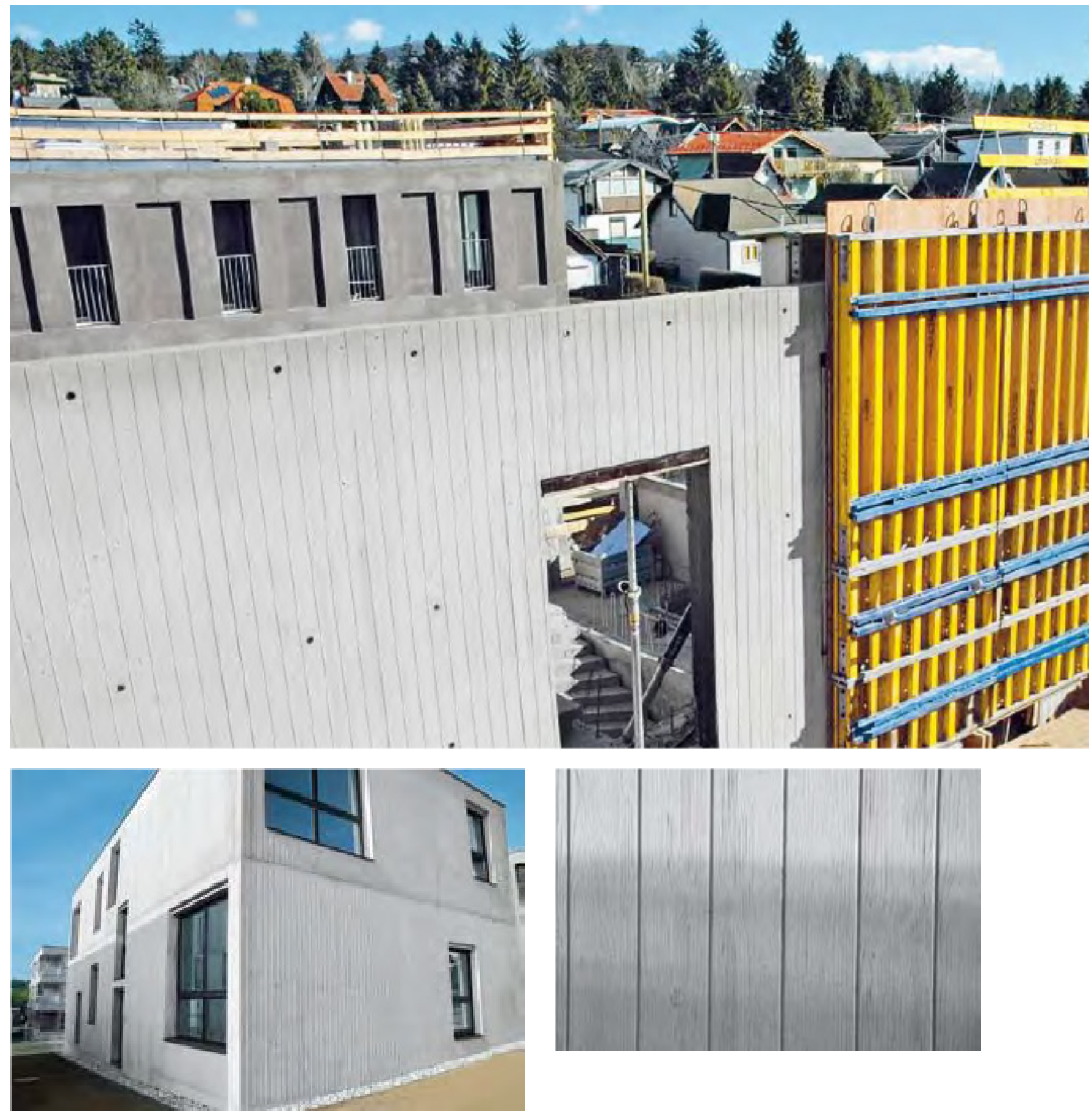




\section{Residential House Han Bit}

Location:

Zurich, Switzerland

Installation and Construction Work:

Toneatti AG, Jona

Architect:

Architectural bureau Burkhalter Sumi, Zurich

Formwork:

Beam formwork Top 50

Bottom:

Wood plank
Residential estate "Han Bit" in Herrliberg is composed of three residential houses. All the front surfaces are made from exposed concrete. For the exposed concrete preframed elements of beam formwork were used, with the panels of sawn planks mounted upon them. At the architect's request, new planks were used after each cycle of concreting.
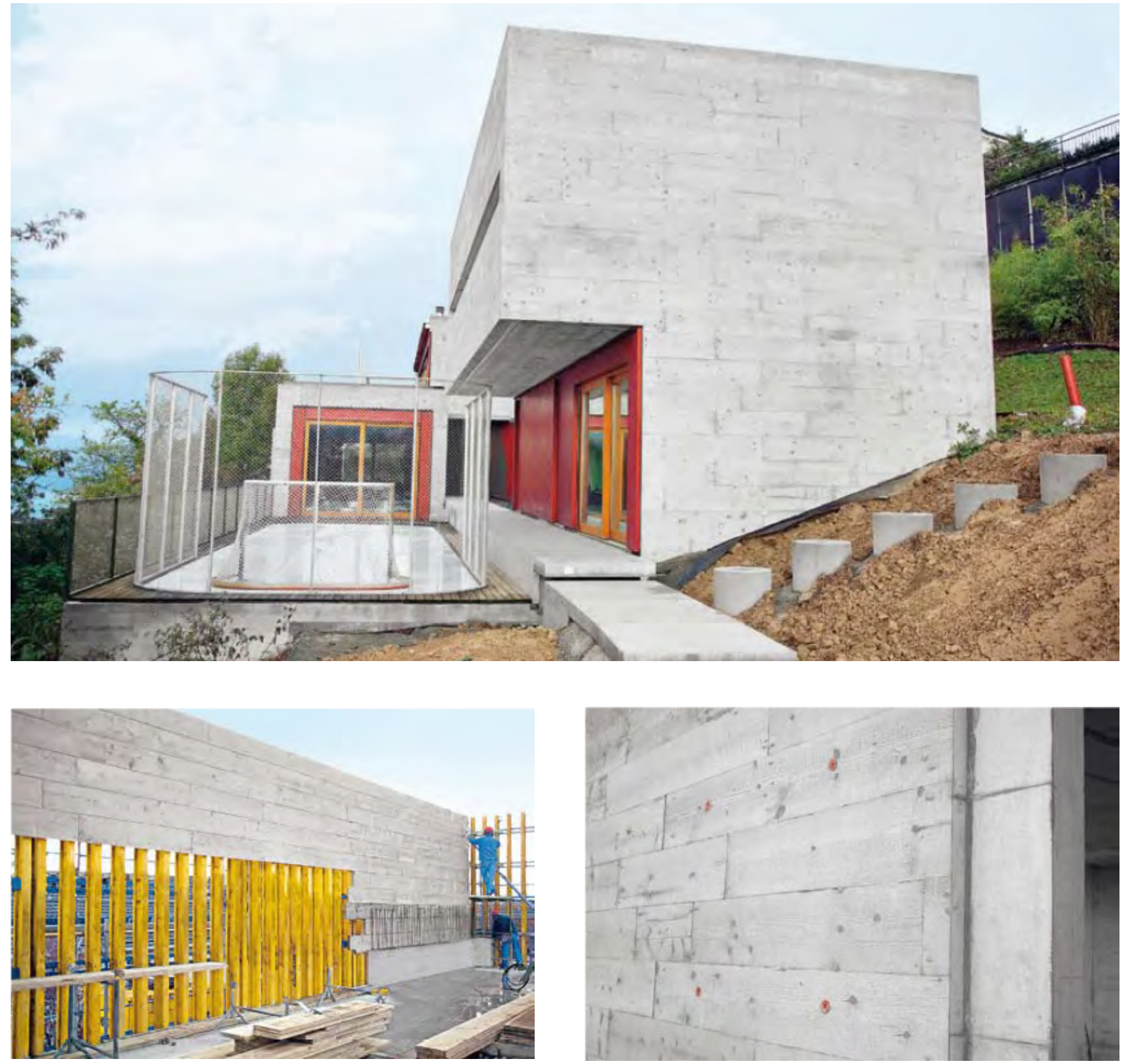


\section{Pharmacy, Ebenthal}

\section{Location:}

Ebenthal, Austria

Installation and Construction Work:

OVEN Bau, Carinthia

Architect:

Trecolore Architects Bureau (Architectural bureau Dorn Ziviltechniker $\mathrm{GmbH}$, Annenheim)

\section{Formwork:}

Frame formwork Framax

Round formwork H2O

Bottom:

Sandwich slab with film coating

Peculiarities:

The concrete ring was concreted in lying position, and then set vertically by means of a hinge.
The basic elements of the building are 2 bent reinforced concrete beams, which contribute to necessary stableness and unusual appearance. Each reinforced concrete beam is 26 meters in length, 9 meters in height and weighs about 131 tons. Manufacturing of such large beams required a special technology. The reinforced concrete beams were poured with concrete in lying position and connected with the foundation by means of steel hinges. Then the beams were set into the position for installation using truck cranes; the hinges were welded to the structure and then poured with concrete.
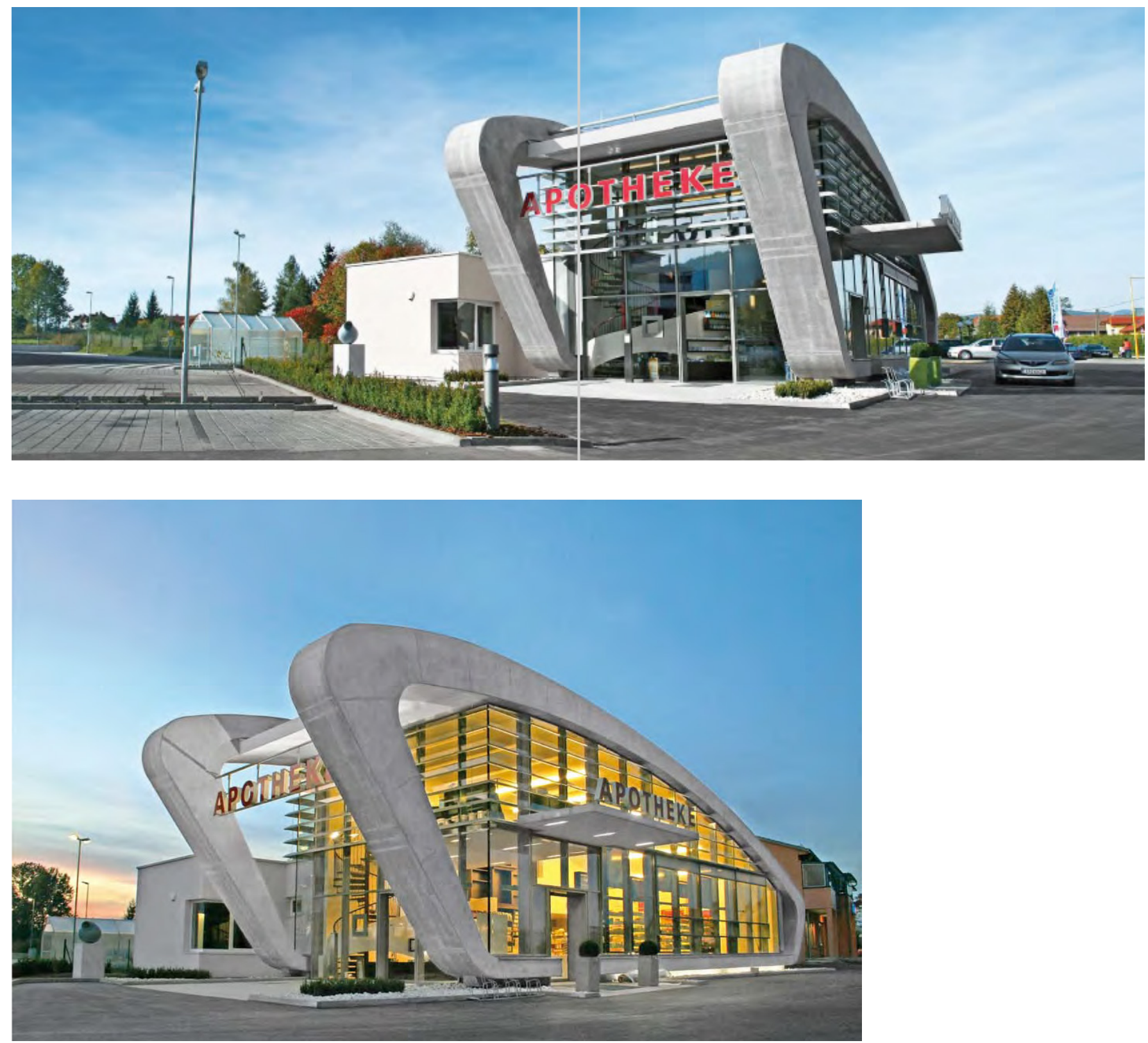


\section{Görtz Shoe House}

Location:

Hannover, Germany

Installation and Construction Work:

Wilhelm Wallbrecht GmbH Co KG, Hannover

Architect:

Bureau BLOCHER BLOCHER Partners, Stuttgart

Formwork:

Elements of the FF20 beam formwork, partially with timbered bottom, wood structures for big embedded formwork

\section{Bottom:}

Formwork sheets Dokaplex, Sandwich slab with film coatingPeculiarities:

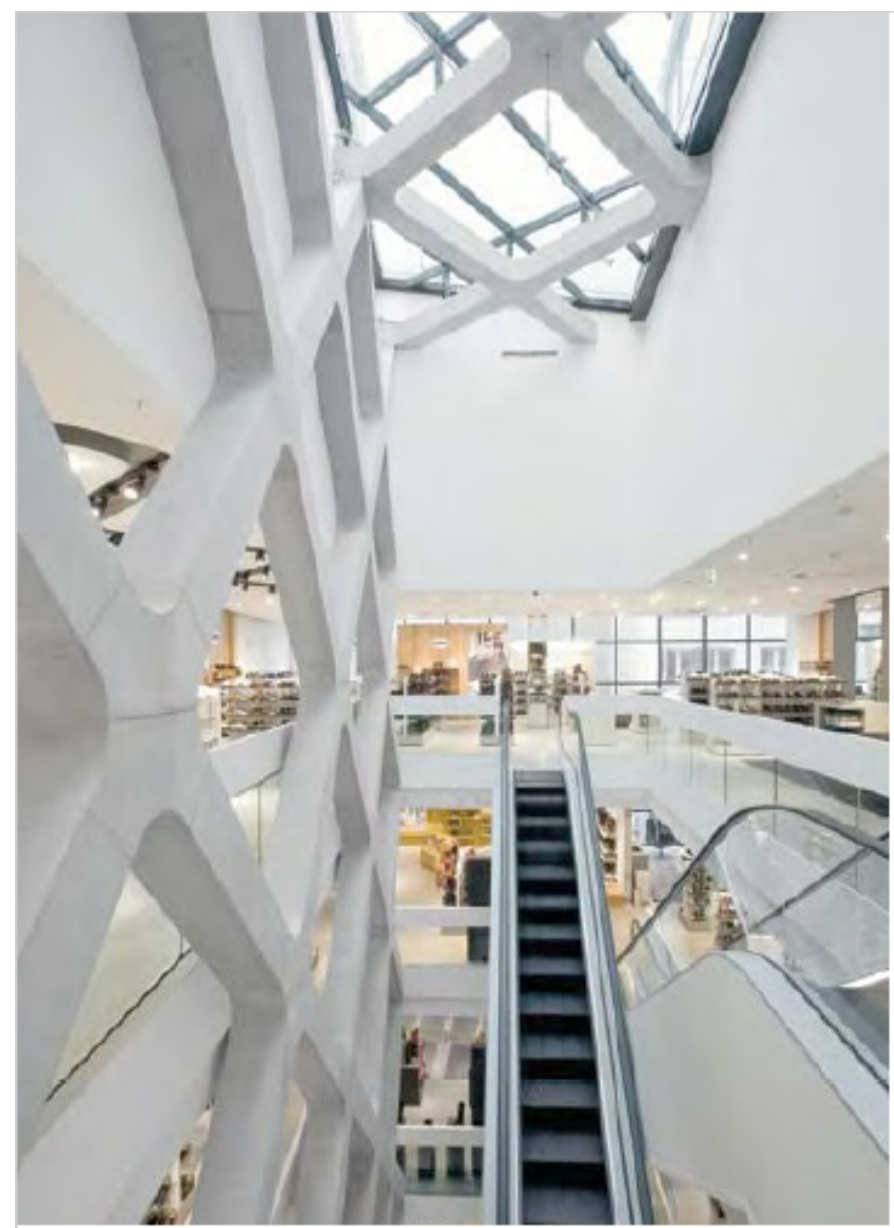

For internal rounding of small radius, painted molded plywood was applied. The new six-floored building of the Görtz Shoe and Accessories House, with the modernization cost about ten million Euro, is notable for its attractive play of architectural shapes. One of its peculiarities is the bearing diamond-shaped structure made from cast-inplace concrete, topping the exit from the escalator. The closed structure composed by three X-shaped crosses, forms a zigzag line at the height of the top floor structure, and, at the same time, plays the role of a bearing structure for the glass roof of the escalator.
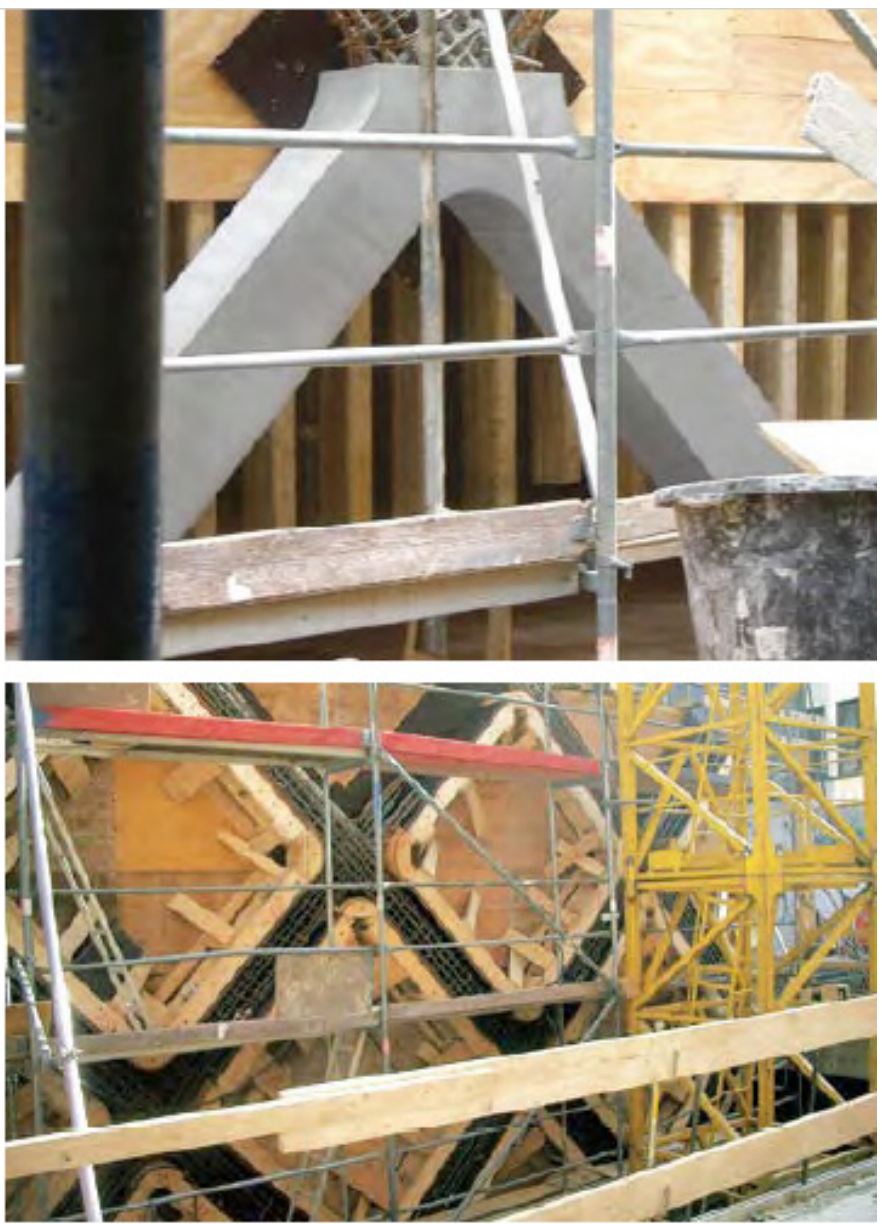
Office Building of the E.ON Group Corporation

Location:

Zolling, Germany

Installation and Construction Work:

Porr (Germany), Murnau, (the Netherlands)

Architect:

Boesel Benkert Hohberg, Architekten, Munich

Formwork:

Frame formwork Framax Xlife, Dokamatic-table

Bottom:

Xlife-slab

Peculiarities:

An inclined building with haunches beneath the floor structures.
In Zolling, near the power station of the electricity sector group of companies E.ON Kraftwerke $\mathrm{GmbH}$, the office building is erected at a very limited space. The energy-efficient compact building of about $13 \mathrm{~m}$ in height is built with the maximum use of exposed concrete and is inclined to the south for more efficient use of the daylight. The angle is equal to $26^{\circ}$, which causes trapezoidal lateral walls, while the facades are inclined forward in the southern side and backward in the northern side. The walls and internal layers of the floor structure in the entrance area, placed centrally, in the fire house, located in the western flank and at the typical floors of $3.30 \mathrm{~m}$ in height are finished by exposed concrete of the 3rd class according to the DBV Regulation.
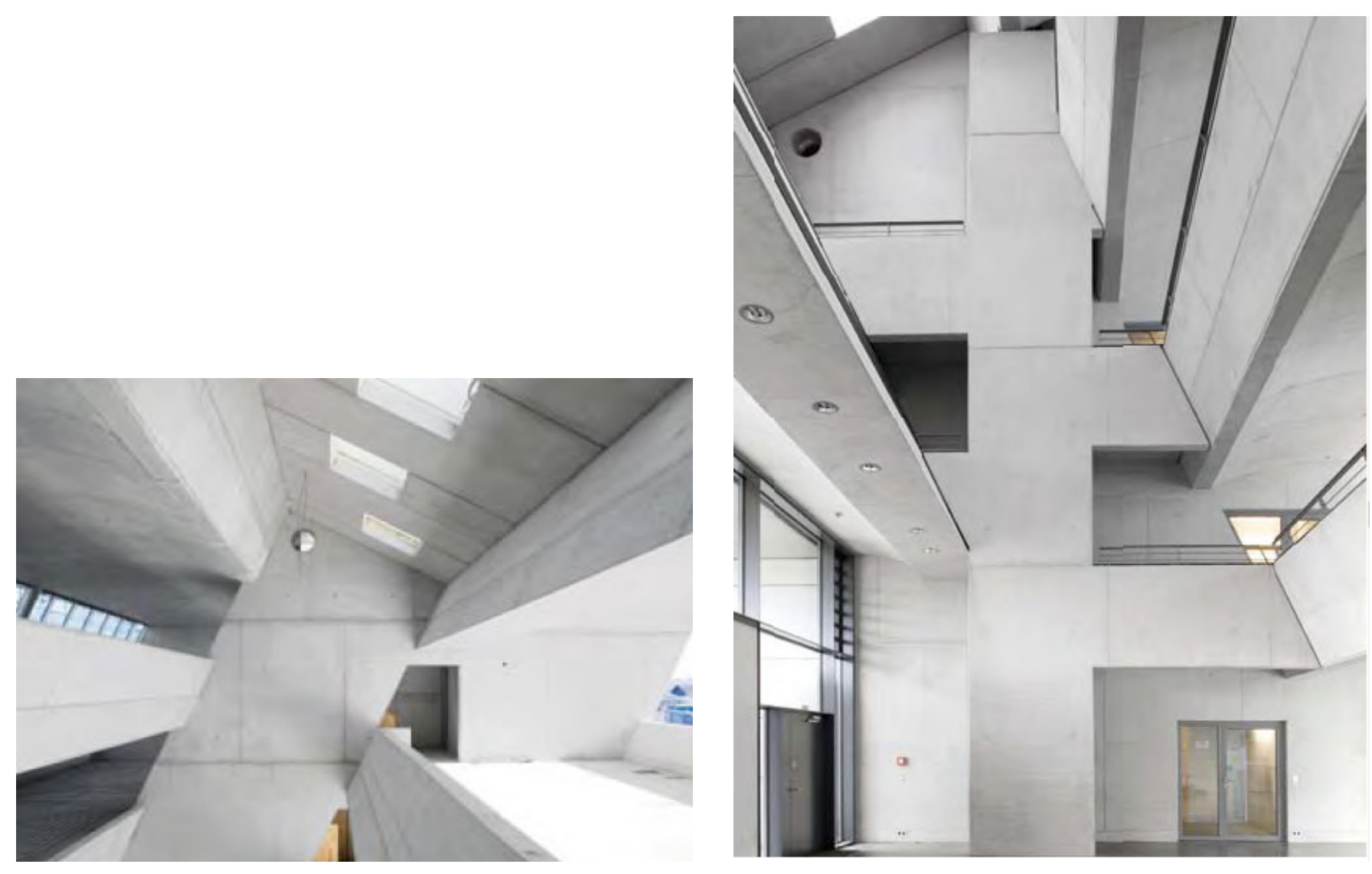


\section{New Multi-Purpose Building}

Location:

Sotto il Monte Giovanni XXIII, Italy

Installation and Construction Work:

Edil Scavil

Architect:

Antonio Gonella

Formwork:

Beam formwork Top 50

Bottom:

Structural slab 3-SO

Peculiarities:

Self-compacting concrete (SVB), wood texture printing on the concrete surface.

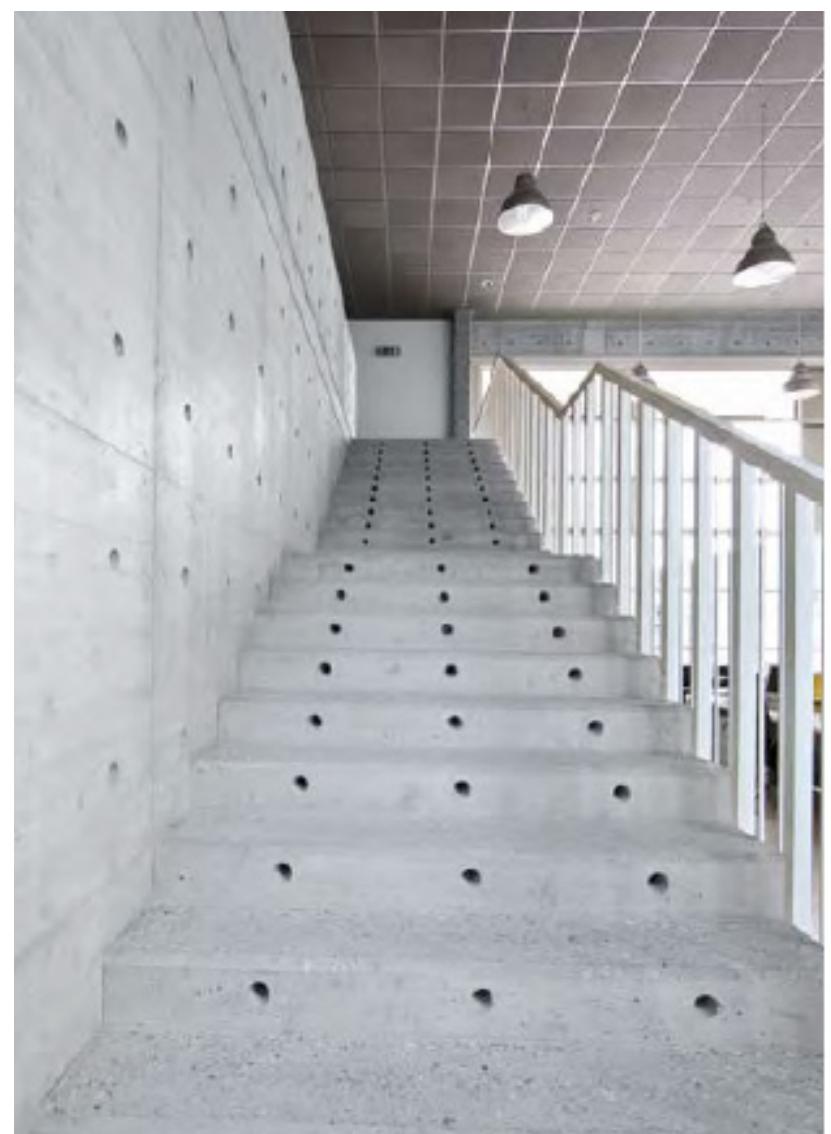

This multi-purpose building is finished by exposed concrete and designed by architect Antonio Gonella at the commission of Arge Edil Scavil srl, Costruzioni Edilcar di Albano S.A. и I.M.I di Piantoni Enzo. The building, decorated by a long travertine colonnade in front of the main facade, is made entirely from self-compacting concrete. The Top 50 beam formwork was delivered at the construction site being totally assembled, which allowed reducing the labor cost. The anchor step calculated by the architect forms an aesthetic pattern on the exposed concrete walls in the internal rooms.

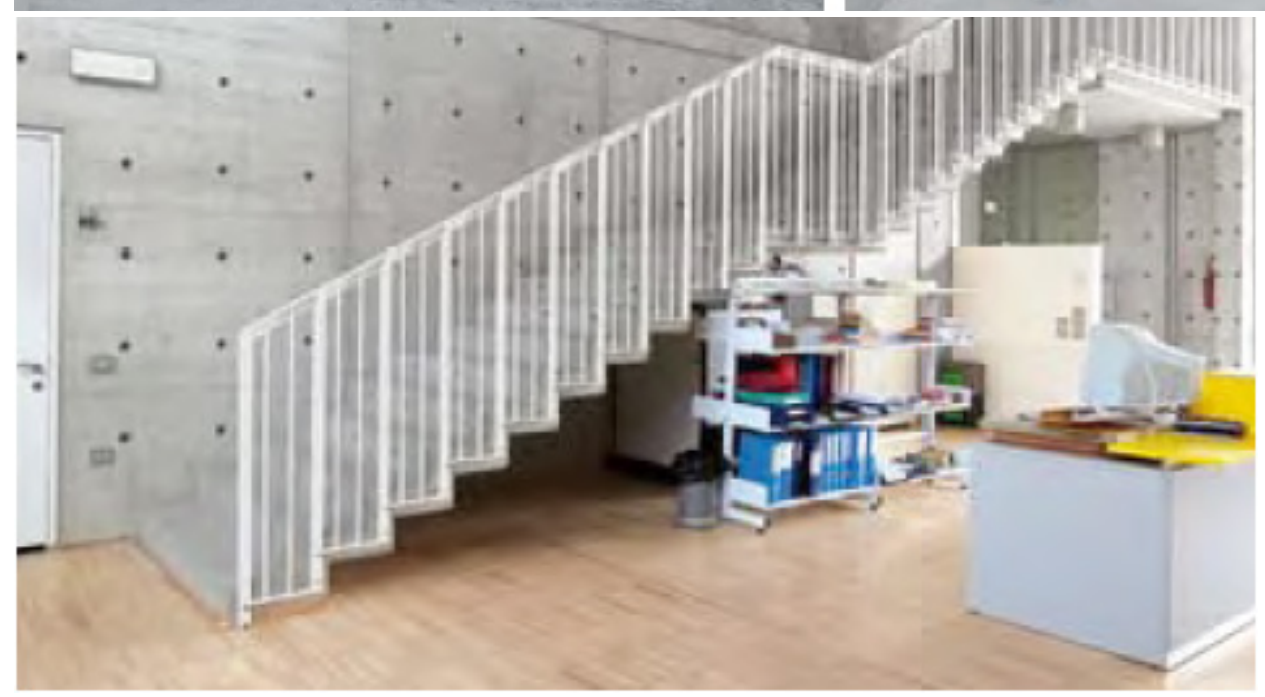


Phaeno Science Center in Wolfsburg

Location:

Wolfsburg, Germany

Installation and Construction Work:

E. Heitkamp

Architect:

Architectural bureaus Zaha Hadid Ltd \& Mayer Bährle

Freie Architekten BDA

Formwork:

Beam formwork Top 50

Bottom:

Timber formwork

Peculiarities:

SVB concrete, geometry of the structure
What the formwork concerns, the building of the Phaeno Science Center with its unique geometry and requirements to the quality of exposed concrete breaks all the traditional views. The applied construction material broadens the scales: the building was predominantly built with the use of SVB concrete.
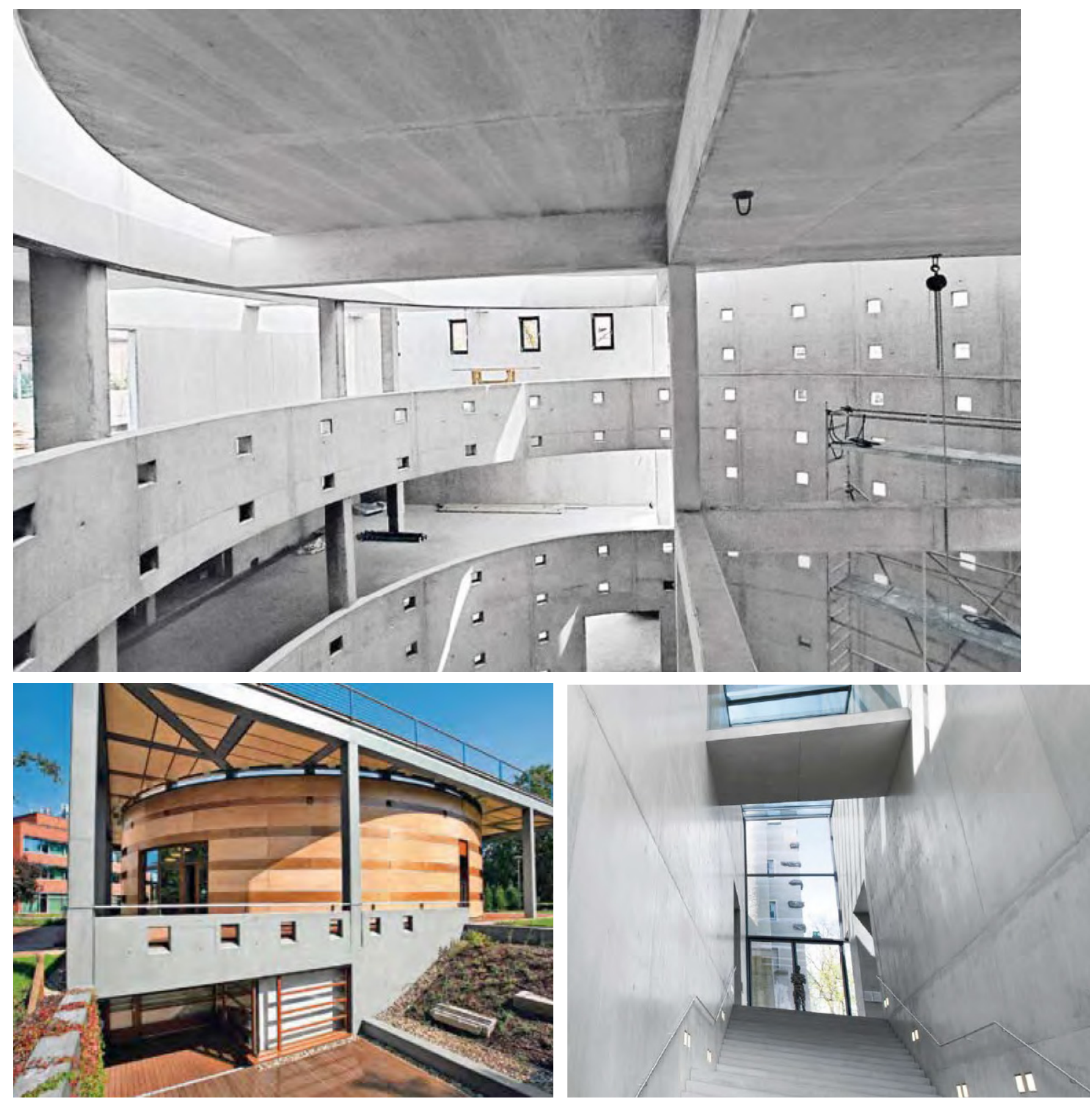


\section{Architecture and Engineering Volume 1 Issue 2}

\section{Head Office of the Graphisoft Company}

Location:

Budapest, Hungary

Installation and Construction Work:

Gév-Huniber Kft.

Architect:

TEN Építész Müterem Bt.

Formwork:

Frame formwork Framax Xlife

Beam formwork Top 50

Round formwork $\mathrm{H} 20$

Bottom:

Sandwich slab with film coating, structural slab 3-SO
For construction of this building, which was awarded by an architectural prize, the Top 50 beam formwork was used. The exposed concrete walls are underlined by many "windows" obtained through embedded formwork, which were attached to the formwork elements by nails.
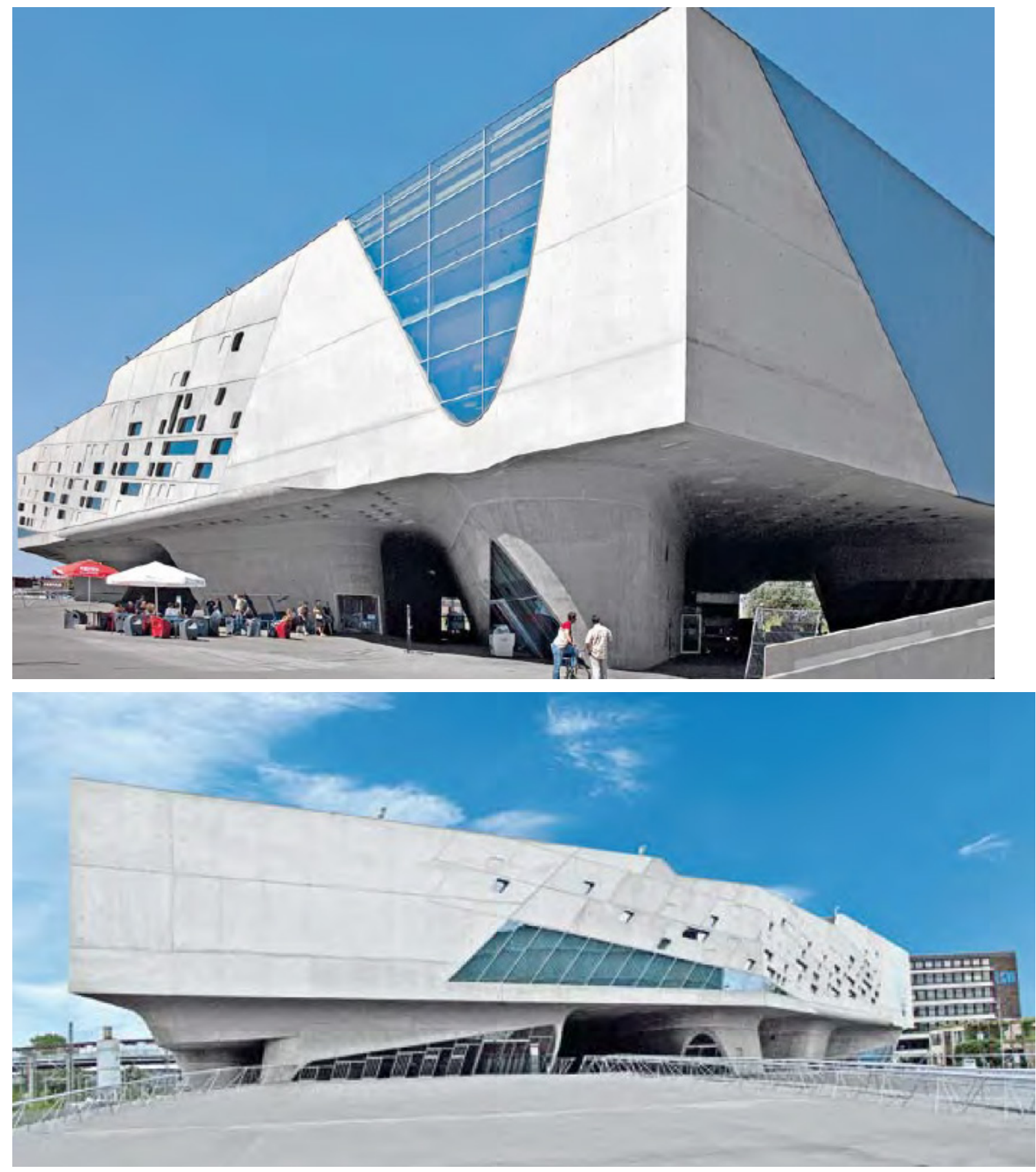
Gallery of Contemporary Art

Location:

Munich, Germany

Installation and Construction Work:

Alpine Bau Deutschland AG, Eching

Architect:

Stephan Braunfels

Formwork:

Beam formwork Top 50

Bottom:

Sandwich slab with film coating

Peculiarities:

Bulky joints
The largest contemporary art gallery in Germany with the total area of show rooms equal to about $15,000 \mathrm{~m}^{2}$ is turned about to the city center by its southern side with the transparent facade of the winter garden, while from the northern side there is a view to the Old and New Gallery. The exposed concrete facade is solved as a thin-walled membrane from monolithic concrete with a calculated joint step of $5.6 \mathrm{~m} \times 2.6 \mathrm{~m}$, with the raised pattern at the area of the bottom joints with sharp edges.
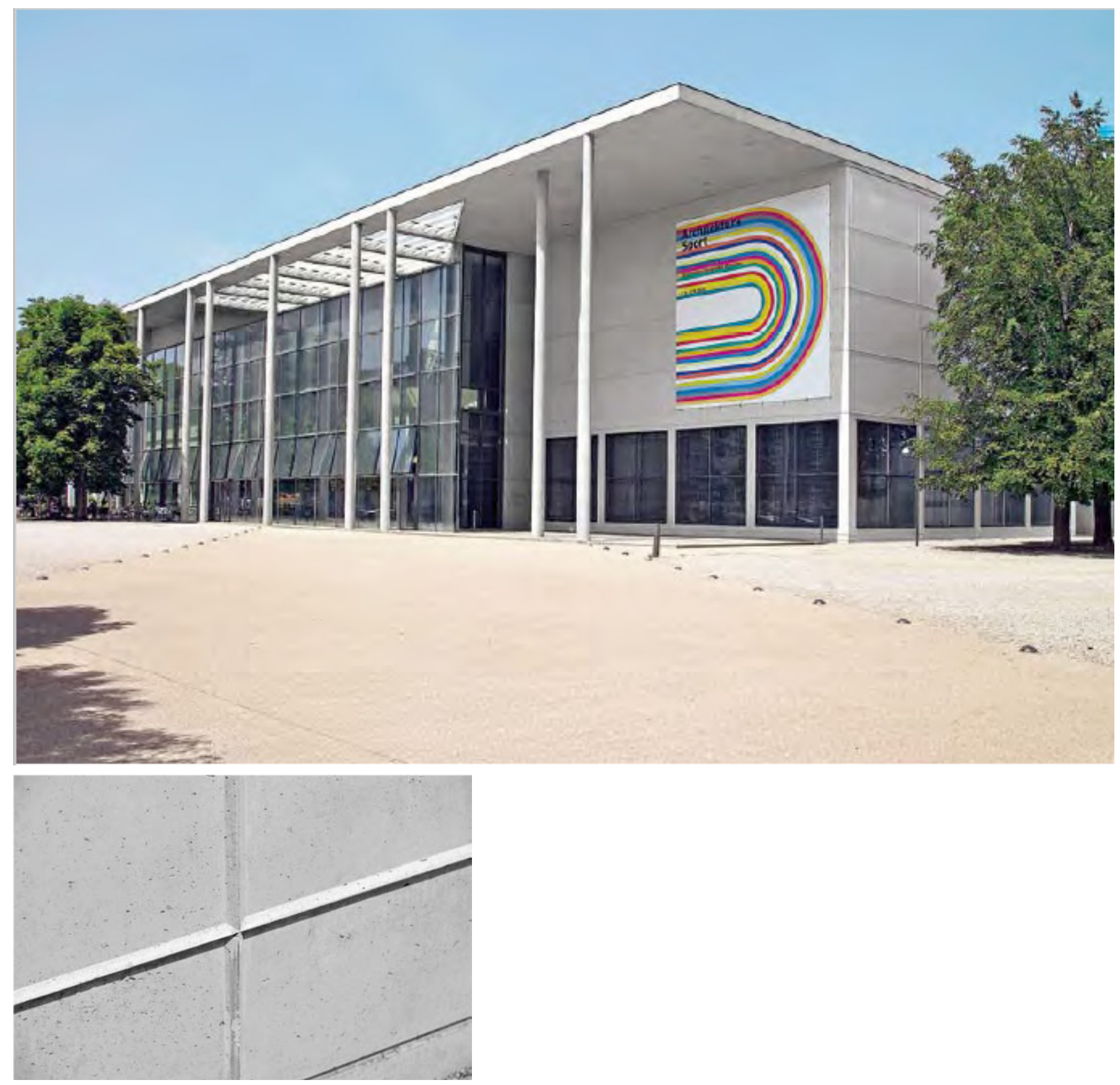


\section{Conclusions}

The technology of exposed concrete allows designing brand new modern unique buildings and structures of special geometry and natural surface facture. Research of the technology of exposed concrete will make it possible to propel the entire technology of concreting to a new professional level. It will contribute to change the attitude towards concrete works and subsequently refuse from external and interior finishing. It is no secret that many builders conceal the defects in the bearing structures by coating them with the finishing layer, so it may be said with full confidence that the buildings and structures with exposed concrete surfaces will be more reliable and will have better performance figures.

The insight into the implemented designs of the European countries carried out in the present paper showed that this technology is not only successfully used in construction, but it is also being thoroughly studied and improved.

When studying this technology, we have the purpose of rendering practical help to construction companies, implementing designs with the use of formwork for the front surface of concrete in the structures being under construction.

\section{References}

Bazhenov YuM (2003) Tekhnologiya betona [Concrete Technology]. 3rd edition. ASV Publishing House, Moscow, RF (in Russian). Cassar L, (2004) Photocatalysis of cementitious materials: clean buildings and clean air. Mrs Bulletin, 29(05): 328-331.

Deutscher Beton- und Bautechnik-Verein e.V. (DBV) Bundesverband der Deutschen Zementindustrie (BDZ) (2015) Merkblatt Fassung Juni 2015. Sichtbeton [Leaflet amended June 2015. Exposed concrete]. Berlin, Deutschland

Gusev YuV (ed.) (2014) Sobytiya i Fakty [Events and facts]. Stroitel'stvo, novye tekhnologii, novoe oborudovanie [Construction Engineering, New Technologies, New Equipment], 10: 9 (in Russian).

Heess S (2009) Architectural concrete with Dyckerhoff Weiss: Design and execution of architectural concrete surfaces. Betonwerk+ Fertigteil-Technik, 75(7): 16-26.

Korchagina OA (2004) Betony i stroitel'nye rastvory [Concretes and Mortars]. Izdatel'stvo TGTU, Tambov, RF (in Russian).

Litzner H-U, Goldammer K-R (2005) Philosophy of the new DBV/BDZ-code of practice 'Architectural Concrete' [Philosophie des neuen DBV/BDZ-merkblattes 'sichtbeton']. Beton- und Stahlbetonbau, 100 (6), pp. 489-495.

Ministerstvo zhilishchno-kommunal'nogo khozyaistva RSFSR, Mosstroikomitet i Glavmosarkhitektura pri Mosgorispolkome (1992) GOST 17608-91: Tekhnicheskie usloviya. plity betonnye trotuarnye. (s izmeneniem №1) [Specifications. concrete paving slabs. (With change №1). Moscow, SSSR (in Russian).

Nekrasova NA, Nekrasov SI, Sadikova OG (2008) Tematicheskii filosofskii slovar': Uchebnoe posobie [Discipline-Related Philosophic Dictionary: Study Guide]. MGU PS (MIIT), Moscow, RF (in Russian).

Rossiiskaya Federatsiya (1995) 169-\$3: FEDERAL"NYI ZAKON OB ARKhITEKTURNOI DEYaTEL"NOSTI V ROSSIISKOI FEDERATsIl [Federal Low on the Architectural Activity in the Russian Federation]. Moscow, RF (in Russian).

Shild E (1982). Stroitel'naya fizika [Structural Physics]. Stroiizdat, Moscow, Russia (in Russian).

Shilstone Sr JM (1985) Architectural concrete contract documents. Concrete International, 7(11): 48-56. 